WITOLD STARNAWSKI

Wydział Nauk Pedagogicznych

Uniwersytet Kardynała Stefana Wyszyńskiego

Warszawa
Forum Pedagogiczne $2017 / 2$

Wpłynęło: 02.12.2016 Zatwierdzono do druku: 12.05.2017 DOI: $10.21697 /$ fp.2017.2.13

\title{
PRIMUM NON NOCERE... UWAGI NA TEMAT UWARUNKOWAŃ EDUKACJI FILOZOFICZNEJ/MORALNEJ
}

\begin{abstract}
Streszczenie: Głównym tematem artykułu jest sprawa celów, treści i sposobów realizacji edukacji filozoficzne/moralnej. Autor opiera się na dwu założeniach: 1) kształtowanie filozoficznej i moralnej refleksji jest jednym z najważniejszych wskaźników dojrzałej osobowości; 2) szkoła nie może uchylać się od podejmowania zadań wychowawczych. Realizacja tego rodzaju edukacji może jednak w praktyce powodować trudności, a nawet niebezpieczeństwa dla prawidłowego rozwoju osobowości młodego człowieka. Występują one na poziomie ideologicznym (tu spowodowane są przez skutki kryzysu cywilizacji zachodniej: kwestia prawdy, sceptycyzm) lub dydaktycznym (zbyt trudne i zbyt abstrakcyjne tematy oraz terminologia niedostosowana do młodych ludzi). Propozycja „filozofii szkolnej” (etyki), zdaniem autora, powinna opierać się na następujących założeniach: 1) filozofia (etyka) winna być przedstawiana jako bezinteresowne poznanie i działanie skierowane ku prawdzie i dobru; 2) młodzi ludzie powinni mieć świadomość, że proponuje się im wprowadzenie do filozofii (propedeutykę), a „prawdziwa filozofia” jest ciągle przed nimi; 3) edukacja powinna opierać się w większym stopniu na doświadczeniu niż na wiedzy abstrakcyjnej; 4) należy umacniać przekonanie, że wszelka wiedza powinna być sprawdzalna (weryfikowalna). Ostatnią rozważaną kwestią jest sprawa zaangażowania nauczyciela.
\end{abstract}

Słowa kluczowe: edukacja filozoficzna, edukacja moralna, doświadczenie, wiedza abstrakcyjna, zaangażowanie nauczyciela.

Zadania systemu oświaty w zakresie kształcenia moralnego to zagadnienie, które wymaga wnikliwego rozpatrzenia co najmniej z dwóch powodów. Po pierwsze dlatego, że w istotny sposób związane jest z wychowawczą misją szkoły. Po drugie zaś - z uwagi na filozoficzny kontekst, w który jest uwikłane, a to sprawia, że realizacja tego zadania może przybierać bardzo różne, niekiedy kontrowersyjne formy, w zależności od rozstrzygnięć dotyczących celów, treści i metod wyznaczonych przez autorów przygotowujących konkretne programy. Potrzeba krytycznego spojrzenia i formułowane przy tej okazji ogólne i szczegółowe zastrzeżenia dotyczące nauczania filozofii i etyki w szkole (w ramach systemu oświatowego) nie mają na celu podważania zasadności 
tej formy kształcenia/wychowywania. Przeciwnie, opierają się na przekonaniu, że jest to zbyt ważna sprawa, aby można było sobie pozwolić na realizację działań bez dokładnego rozważenia wszelkich okoliczności i uwarunkowań.

Wydaje się, że jako niekwestionowalne można przyjąć dwa założenia wyznaczające ramy dyskusji w tej kwestii. Po pierwsze, rozbudzenie refleksji filozoficznej i pogłębienie wrażliwości moralnej to jeden z ważniejszych wskaźników dojrzałej osobowości. Po drugie zaś, szkoła nie może (nie powinna) uchylać się od zadań wychowawczych. Założenia te pozwalają określić wstępne warunki związane z procesem „kształcenia moralnego” (filozoficznego) oraz pomagają odsłonić niektóre z zagrożeń, które mogą sprawić, że nawet kierowane dobrymi intencjami działania mogą przynieść odwrotne od zamierzonych skutki. Jedną z najważniejszych kwestii jest wypracowanie kryteriów oceny realizowanych projektów oraz proponowanych eksperymentów. Ocena ta powinna być przeprowadzona przede wszystkim z punktu widzenia dobra odbiorcy/ucznia/wychowanka, nie zaś z perspektywy systemu oświatowego, autorów programu czy jego realizatorów.

Kwestia kształcenia moralnego generuje kilka problemów, którym należy uważnie się przyjrzeć, aby przygotowane propozycje służyły budowaniu dojrzałej osobowości i efektywne realizowały wychowawcze zadanie szkoły.

1. Niebezpieczeństwo ideologizacji filozofii i etyki - istnieje ono zawsze, gdyż filozofia w naturalny sposób stanowi podstawę ideologii i światopoglądu. Włączenie nauczania filozofii/etyki do systemu oświatowego (wychowawczego) znacznie zwiększa groźbę jej odgórnego ukierunkowania oraz instrumentalizacji przez władze. W Polsce niebezpieczeństwo to wzrosło na skutek nieprzemyślanych decyzji władz oświatowych i złej praktyki - chodzi o usytuowanie etyki w szkole, co w praktyce może prowadzić do traktowania jej jako „antykatechezy” czy „świeckiej katechezy”10.

2. Przeniesienie na poziom szkoły skutków poważnego kryzysu kulturowo-cywilizacyjnego i „zainfekowanie” szkoły kryzysem. Najpoważniejszym jego przejawem w „społeczeństwie dorosłych” jest negowanie potrzeby poszukiwania prawdy, kwestionowanie uniwersalistycznie rozumianej płaszczyzny dialogu i sporu (na rzecz lokalnie obowiązujących narracji), usuwanie zasady racji (potrzeby uzasadniania) na rzecz zasady wyboru ${ }^{11}$.

10 Maciej Wasilewski, autor podręcznika do etyki (Pomiędzy jasna a ciemną strona mocy. Ty wybierasz...) wskazując we wstępie na różnice między etyką a religią, kończy taką „zachętą”: „Czy znajdziecie odpowiedzi na wszystkie pytania, z powodu których wybraliście etykę, a nie religię? Nie wiem, ale zachęcam was - nauczycieli i uczniów - do rozmowy" (2014, s. 8). Jak widać, to przeciwstawienie ma nie tylko praktyczny wyraz, ale zmierza do teoretycznego uzasadnienia.

11 Leszek Kołakowski w jednym ze swoich esejów zwraca uwagę, że postmodernizm, chcąc unicestwić „prawdę jako osobną wartość życia i prawomocny cel” (2009, s. 307-308), uznając prawdę w znaczeniu tradycyjnym za przesąd, przecenia własne możliwości i sam powoli obumrze. Nie zmienia to jednak faktu, że zanim przestanie być modny i zniknie, poczynić może znaczne szkody, trwające długo po jego - przewidywanym - upadku. 
3. Specyficzne rozumienie pluralizmu (jako kakofonii) wynikające m.in. z wprowadzania do nauk społecznych i humanistycznych, zwłaszcza do pedagogiki, swoiście rozumianej „wieloparadygmatyczności”, która miałaby w sposób "nieinwazyjny” rozwiązywać problemy powstałe po usunięciu uniwersalnego kryterium prawdy. Taka sytuacja może prowadzić do chaosu intelektualnego odbiorcy/ucznia/wychowanka, powiększenia jego dezorientacji i zwątpienia co do możliwości oceny i rozstrzygania proponowanych w szkole i w życiu rozwiązań, a tym samym do zagubienia czy uwstecznienia własnego rozeznania intelektualnego (rozum, roztropność) i moralnego (sumienie). W konsekwencji może to doprowadzić do zmniejszenia lub utraty sprawności dokonywania wyborów moralnych, osłabienia możliwości samorealizacji czy efektywnej orientacji w rzeczywistości.

4. Niedostosowanie tematów, poziomu rozważań, terminologii do etapu rozwoju intelektualnego, emocjonalnego, psychicznego dziecka/młodego człowieka, co w rezultacie prowadzić może do sytuacji, w której przedstawiane treści uznane zostaną za zbyt trudne, za nudne lub będą źle oddziaływać na jego osobowość.

\section{Pochwała filozofii i etyki}

W punkcie wyjścia należy, moim zdaniem, pokreślić znaczenie filozofii i etyki jako wiedzy nieutylitarnej, tzn. niepodporządkowanej innym celom jak tylko poznaniu prawdy - w przypadku filozofii oraz w przypadku etyki - poznaniu dróg dobrego życia, doskonalenia człowieka. Ważne wydaje się więc to, aby w rozstrzyganiu wszelkich kwestii związanych z obecnością filozofii/etyki w szkole uwzględnić ten aspekt bezinteresowności poznawania i działania (ze względu na prawdę i dobro), pozostawiając na drugim miejscu kryteria związane z innymi celami, którymi mogą kierować się twórcy systemu oświatowego (zarządzający nim), nauczyciele, w pewnej mierze również rodzice. Warto zwrócić uwagę, że taki punkt wyjścia zasadniczo nie determinuje jeszcze żadnych rozstrzygnięć merytorycznych, nie musi przesądzać o wyborze jakiejś koncepcji filozofii, etyki.

Równie ważnym przedwstępnym założeniem zdaje się być uświadomienie uczniom/odbiorcom, że celem takich zajęć nie jest przede wszystkim zdobycie jakieś wiedzy czy umiejętności, ale przygotowanie do podjęcia samodzielnej „aktywności poznawczej” i „działalności” służącej własnemu udoskonaleniu umysłowemu i duchowemu. Ważne jest uświadamianie uczniom, że wprawdzie potrzebna jest tu pomoc i ukierunkowanie ze strony nauczyciela, niemniej zasadnicza jest postawa i aktywność samego ucznia, i ostatecznie to on sam odpowiada za rezultaty tej „pracy”, daleko wykraczające poza ramy szkolnej edukacji ${ }^{12}$.

12 Trudno nie przywołać w tym miejscu pionierskich prac i działań Wandy Kamińskiej w dziedzinie dydaktyki filozofii (Kamińska 2014; Kamińska, Jasiński 2014). Można mieć nadzieję, że 


\section{Filozofia/etyka w szkole - po co?, dla kogo?}

Przyjęcie takiego uniwersalistycznego rozumienia filozofii i etyki nie daje jeszcze wystarczających podstaw do akceptacji tezy, że filozofia/etyka powinna być nauczana w szkole. Wydaje się, że nie jest nawet wystarczającym argumentem stwierdzenie, że poszukiwanie prawdy, sensu życia, potrzeba rozeznawania celów, dokonywania właściwych ocen moralnych są rozwinięciem naturalnych potrzeb intelektualno-duchowych młodego człowieka. Jest to ważna, ale nie decydująca przesłanka. W dziedzinie wychowania, podobnie jak w sztuce lekarskiej, zanim przystąpi się do działania zmierzającego do dobrego celu, należy się upewnić, czy nie przyniesie ono więcej szkody lub czy samo jego podjęcie nie będzie stanowić w pewnych okolicznościach poważnego zagrożenia. W wychowaniu, w jeszcze większym stopniu niż w medycynie, nie można sobie pozwolić na stosowanie nieprzygotowanych eksperymentów, chodzi bowiem o wartości ważniejsze niż zdrowie. Świadomość zagrożeń nie może być tylko „jednym z wielu” czynników oceny projektów, lecz powinna być warunkiem wstępnym dopuszczenia ich do realizacji. Istnieją przecież działania wychowawcze, która przynoszą wątpliwe lub wręcz szkodliwe skutki, a wychowanie staje się zaprzeczeniem siebie, staje się pseudowychowaniem (Filek 2001).

Należy zatem rozważyć - w zależności od wieku uczniów, jak i od tego, czy jest to propozycja skierowana do wszystkich, do tych, którzy zechcą ją podjąć, do wybranych, do wyselekcjonowanych według różnych kryteriów - czy i jakie skutki niepożądane może przynieść edukacja filozoficzna, a nawet - czy może być szkodliwa dla rozwoju osobowościowego (jakiejś fazy tego rozwoju). Nie wystarczy sam „entuzjazm dla filozofii” ani przekonanie, że nauczanie filozofii samo w sobie stanowi wartość i powinno być upowszechniane bez bliższego określenia celu, okoliczności, wieku, możliwości i potrzeb odbiorców ${ }^{13}$.

zaangażowanie naukowe i wnikliwość teoretyczna na tym polu będą stanowić pomost do praktyki i rozjaśnią, a nie zaciemnią, pedagogiczny charakter dydaktyki oraz pogłębią rozumienie pedagogicznego potencjału filozofii.

13 Jako przykład takich nie do końca przemyślanych i niedostosowanych do wieku działań można podać propozycję lekcji o tolerancji realizowanej w klasach 1-3 szkoły podstawowej. Według relacji nauczycielki, lekcja ta przebiegała w taki sposób: - „Ostatnio mieliśmy lekcję o kryteriach piękna. Dzieci wybierały zdjęcia różnych ludzi i tłumaczyły, dlaczego się podobają. Była ostra dyskusja, np. czy tylko młodzi mogą być piękni. A ten to gej, powiedział jeden z uczniów o mężczyźnie na zdjęciu. Pytam, dlaczego. To przecież widać, odpowiedział” - mówi Janina Tyszkiewicz, nauczycielka etyki w podstawówce na warszawskim Bemowie. - „Na następnych zajęciach wymieszałam zdjęcia osób homo- i heteroseksualnych i mieli wybierać. Kłócili się, przebierali, oczywiście wyszło, że się nie da. No i spontanicznie zrobiła nam się z tego lekcja o tolerancji", http://www.polityka.pl/tygodnikpolityka/spoleczenstwo/1531799,1,czego-sie-uczy-na-lekcjach-etyki.read (otwarty: 26.10.2015 roku). 


\section{Filozofia - dla dorosłych, dla młodych (adeptów) - propedeutyka}

W dziedzinie, o której mówimy - jak rzadko w której - ważne jest to, co się mówi, kto i jak mówi. Pierwsza kwestia („co się mówi”) nie dotyczy tylko wyboru treści, lecz moim zdaniem zawiera poważniejszy problem. Chodzi o rozstrzygnięcie problemu, w jakiej mierze i w jakim stopniu powinno wejść się w samą filozofię, a w jakiej tylko we wstęp do niej. Wtórną jest inna kwestia, czy będzie to ujęcie systemowe, historyczne, czy metateoretyczne. Moim zdaniem powinna to być propedeutyka filozofii z elementami „filozofowania osobistego”, a więc jakiejś „amatorskiej filozofii" (co nie umniejsza tej formy filozofowania, jest ona ważna, zwłaszcza na pierwszym etapie, i warto pamiętać, że w pewnym sensie od niego rozpoczyna się wszelkie filozofowanie).

Tak sformułowany postulat nie wyznacza żadnej reguły, nie oznacza, że „prawdziwa filozofia” jest „tylko dla dorosłych” (choć dla młodych byłby to bardzo atrakcyjny zakaz). Chcę tylko zwrócić uwagę na zbyt chyba lekceważoną prawdę, że filozofia (niekoniecznie mam na myśli filozofię akademicką czy uprawianą przez "zawodowych filozofów”) wymaga nie tylko sprawności intelektualnej, ale przede wszystkich dojrzałości osobowej i bogatego zasobu doświadczeń, w które młody człowiek rzadko kiedy jest wyposażony (co oczywiście nie znaczy, że dorosły ma je zawsze). W tym znaczeniu ujmowanie wydarzeń w perspektywie czasowej, umiejętność dystansowania się do tego, co się dzieje obecnie, pogłębiona zdolność obiektywizacji, refleksji i autorefleksji wydają się ważnymi czynnikami uprawiania filozofii. Istnieje tu zagrożenie, że zainteresowania filozoficzne, wyrażające się w poszukiwaniu sensu życia, zaintrygowanie problemami egzystencjalnymi, zainteresowanie problematyką moralną - mające w okresie młodości naturalny charakter - zostaną uznane za samą filozofię. I słuszne skądinąd przekonanie, że życie i doświadczenia każdego człowieka oraz doświadczenie potoczne i refleksja osobista stanowią dobry punkt wyjścia dla uprawiania filozofii zmienią się w przekonanie, że poziom ten jest wystarczający i że każdy ma prawo mieć „swoją filozofię". Taka subiektywistyczna redukcja filozofii przyznająca każdemu prawo do jej „posiadania” i tworzenia może również prowadzić do promowania amatorszczyzny oraz bylejakości poznawczej i metodologicznej, a więc do podważania zasadności intelektualnego wysiłku, lekceważenia metody, potrzeby precyzji, racjonalności poglądów, spójności prezentowanych koncepcji. Wydaje się, że szkolna filozofia/ etyka powinna pozostać na poziomie wprowadzenia, propedeutyki i że należy uświadamiać uczniom, że prawdziwa filozofia jest jeszcze przed nimi. Trudno w tym przypadku dokładnie określić proporcje między dwiema opcjami: filozofią 
jako wiedzą dostępną dla każdego i wiedzą wymagającą pewnego „wtajemniczenia”. $\mathrm{O}$ „wtajemniczeniu” można, jak sądzę, mówić co najmniej w dwu znaczeniach. Po pierwsze dlatego, że filozofowanie wymaga przyjęcia postawy rzadko spotykanej w życiu codziennym - dystansu wobec świata, siebie samego, własnego poznawania i przeżywania. Po drugie, dlatego że dociera do granic ludzkiego poznawania i „dotyka” tego, co niedostępne, przekraczające naturalne możliwości rozumu, a więc - do tajemnicy.

\section{Jak uczyć?}

Równie ważna jest forma, w której podaje się treści, a ta w przypadku filozofii i etyki nigdy nie jest tylko formą. Sądzę, że rozwiązaniu występujących tu problemów będzie sprzyjało odrzucenie formalizmu. To znaczy przyjęcie tezy, że sposoby, metody przekazu są czynnikami drugorzędnymi. Co powinno być celem pierwszorzędnym? Rozbudzenie pragnienia poznawania świata, innych ludzi, siebie samego; poznania, które jest całościowe, fundamentalne, poszukuje zasad. A w przypadku etyki poszukiwanie odpowiedzi na pytanie „jak dobrze żyć?”. Kształtowanie takiej postawy równocześnie służy rozwojowi osobowości, poszerza horyzonty poznawcze, uczy dostrzegania tego, co pomija się w doświadczeniu potocznym, ćwiczy uwagę, pogłębia autorefleksję, uczy postawy otwartej, rozważnej, krytycznej, rozwija samodzielność, utrwala potrzebę racjonalnego (uzasadnionego) wyboru, wskazuje zasady kierowania własnym rozwojem, odsłania najgłębsze racje życia społecznego i działania na rzecz innych.

Wydaje się, że działaniu służącemu rozwijaniu takiej postawy pomaga odkrywanie i wzmacnianie tkwiącego w człowieku naturalnego pragnienia poznawania prawdy i szukania odpowiedzi na pytania o dobro. Na znaczenie tej naturalnej potrzeby ludzkiego ducha zwraca uwagę Jan Paweł II w Liście do młodych, pisząc: „Kiedy jednak stawiamy problem oświaty, wykształcenia, nauki i szkół — wyłania się sprawa, która dla człowieka, a w sposób specyficzny dla młodego człowieka, posiada znaczenie zupełnie istotne. Jest to sprawa prawdy. Prawda jest światłem ludzkiego umysłu. Jeżeli od młodości stara się on poznawać rzeczywistość w różnych jej wymiarach, to w tym celu, aby posiąść prawdę: aby żyć prawdą. Taka jest struktura ducha ludzkiego. Głód prawdy stanowi podstawowe jego dążenie i wyraz" (Jan Paweł II 1985, 12).

Wydaje się, że uznanie, iż kształtowanie postawy ciekawości i pogłębionego rozumienia rzeczywistości, jest właściwym przedmiotem i celem szkolnej filozofii/ etyki, rozwiązuje również problem metod. Dostarcza bowiem właściwych racji do ich wyboru oraz zapewnia ich pluralizm. Równocześnie można mieć obawę, że wysiłek skierowany na wydobycie innowacyjności, kreatywności, inspirującego charakteru samych metod, jeśli nie będzie podporządkowany realizacji naturalnej potrzeby poszukiwania prawdy, nie przyniesie pożądanych rezultatów w płaszczyźnie osobowej. 


\section{Wiedza abstrakcyjna}

Należy również z ostrożnością i rozwagą podejść do kwestii opisywania i wyjaśniania młodym ludziom rzeczywistości za pomocą wiedzy abstrakcyjnej ${ }^{14}$. Abstrakcje filozoficzne (idee, pojęcia ogólne, zwłaszcza te, które systematyzują kierunki filozoficzne) bywają dla nich niezrozumiałe; mogą również być szkodliwe, tak jak bywają szkodliwe i w świecie dorosłych, kiedy ktoś zapomina, że abstrakcja filozoficzna jest wiedzą wziętą z doświadczenia, z poznania konkretnych rzeczy i osób oraz że ma służyć poznaniu konkretnej rzeczywistości (tu i teraz), a nie świata bytów ogólnych. Warto również zwrócić uwagę, że często bywa tak, iż dokonywane przez historyków, komentatorów i interpretatorów kategoryzacje i systematyzacje poglądów filozofów, wprowadzając poręczne abstrakty i określając (szufladkując) czyjeś poglądy, w gruncie rzeczy je zaciemniają i czynią je (źródła) trudniej dostępnymi, zwłaszcza dla młodych adeptów.

$Z$ tego również względu, a także z uwagi na dużo mniejszą efektywność, wydaje się, że nie należy stawiać na pierwszym miejscu ujęcia historycznego lub metateoretycznego, ponieważ młodzi ludzie nie są przygotowani do przyjmowania tak dużego ładunku abstrakcyjnej wiedzy ani do jej oceny. Zbyt duża porcja tej wiedzy lub zbyt duży stopień jej trudności (co w przypadku filozofii jest czymś naturalnym) nie rozbudza samodzielności, lecz wymusza raczej bierność. Można sądzić, że powierzchowna wiedza dotycząca wielkich systemów, nieodnosząca się w żaden sposób do zasobów własnego doświadczenia, może przynieść więcej szkody niż pożytku - a więc prowadzić do zniechęcenia, aby poważnie uprawiać filozofię lub może wzmocnić - szczególnie niebezpieczną dla filozofa - pokusę oderwania od rzeczywistości, chęć czynienia zbyt szybkich uogólnień, porównywania i klasyfikowania poprzez różnorakie „-izmy” w przekonaniu, że jest to poziom „wiedzy wyższej”, dający jakąś „władzę” nad rzeczywistością i poczucie wyższości nad innymi („profanami”). Taka postawa jest zresztą zgodna z potocznym rozumieniem filozofii, która miałaby zaciemniać, zamiast rozjaśniać, gmatwać i komplikować to, co proste, wynajdywać problemy tam, gdzie ich nie ma. Dla niektórych młodych ludzi takie rozumienie filozofii może stać się czymś atrakcyjnym w naturalnej skądinąd potrzebie wyróżnienia się, zaznaczenia swojej oryginalności czy chęci prowokowania. Na ile taka postawa okaże się tylko zabawą, przejściową grą czy pozą, niepozostawiającą głębszych śladów w osobowości, zależy od wielu czynników, warto jednak przypominać, że może to być gra niebezpieczna, zwłaszcza dla kogoś, w kim obudzi chęć wcielania w życie przyjętych w taki nierozważny sposób rozwiązań filozoficznych.

14 Wiedza matematyczna jest bardzo potrzebna do wykształcenia ogólnego, lecz trzeba zwrócić uwagę, że abstrakcja matematyczna nie opisuje rzeczywistości, lecz kształtuje umiejętności myślenia. Abstrakcja zaś zawarta w filozofii opisuje rzeczywistość. 
Niebezpieczne może być również preferowanie sceptycznej postawy poznawczej, zwłaszcza jeśli traktuje się ją, idąc za tradycją Kartezjusza, jako obowiązujący punkt wyjścia dla poznania naukowego, a nawet więcej, jako trwałą postawę dyskwalifikującą wszelkie pozytywne rozwiązania jako „dogmatyczne”. Młody człowiek, niepewny swej wiedzy, poszukujący rozwiązań, wątpiący o swoim dotychczasowym poznaniu, podważający wiedzę, którą otrzymał - a taka postawa wyznaczona jest skądinąd naturalnym rozwojem osobowości w tym okresie - otrzymuje jako pewnik to, że nic nie jest pewne. To, co Jan Paweł II nazywa „pokusą sceptycyzmu” (Jan Paweł II 1985, 13), zostaje w ten sposób dodatkowo wzmocnione i może okazać się zbyt silnym bodźcem, aby młody człowiek mógł mu się oprzeć.

\section{Doświadczenie}

Na szczęście filozofia jest czymś więcej niż abstrakcją, jest w niej doświadczenie i intuicja intelektualna oraz potrzeba konfrontowania tez filozoficznych (i etycznych) z rzeczywistością dla potwierdzenia ich wiarygodności (lub falsyfikowania ich $)^{15}$. Nie znaczy to, że należy pomijać te koncepcje, które nie podkreślają związku z rzeczywistością, które bardziej niż światem realnym zdają się być zainteresowane światem idei, językiem lub metodą i w których się utrzymuje, że filozofowanie jest bardziej grą niż poznawaniem. Nawet jednak wtedy pytania filozoficzne zachowują swoją wagę dla człowieka. Rozstrzygnięcie kwestii, które ze stanowisk filozoficznych powinny znaleźć swoje miejsce w szkolnym nauczaniu, nie jest łatwe. Wydaje się, że powinny się w nim znaleźć wszystkie te nurty, które są w danym czasie ważne, szeroko rozpowszechnione czy uznawane za znaczące. Jednak nie na zasadzie jakiejś abstrakcyjnej równoprawności. Wydaje się, że w „filozofii szkolnej” (etyce) powinny być preferowane te, w których obowiązuje zasada weryfikacji wiedzy poprzez szeroko rozumiane doświadczenie. Weryfikacji rozumianej dwojako: 1) jako sprawdzanie obiektywne, konfrontowanie z rzeczywistością głoszonych tez filozoficznych; 2) jako sprawdzanie ich wartości we własnym doświadczeniu.

Systemy i poglądy, w których pomija się lub wręcz odrzuca potrzebę takiej weryfikacji, także powinny być prezentowane, trudno jednak się zgodzić na to, aby były wyłączone z procedury weryfikacji („uzgadniania” z rzeczywistością) ${ }^{16}$. Uczeń powinien mieć możliwość wysłuchania tych „opowieści”, mając świadomość, że o tyle

15 Mam na myśli filozofię w ujęciu klasycznym, w którym się przyjmuje, że dotyczy ona rzeczywistości realnej (nie jest tworzeniem idei) i dostrzega się potrzebę oraz możliwość jej weryfikacji.

16 Niekiedy propozycja filozofii oderwanej od rzeczywistości może stać się atrakcyjną ofertą dydaktyczną i wychowawczą. Ewa Bogusz-Bołtuć używa do tego celu określenia filozofii Gilesa Deleuze'a i Félixa Guattariego: „Filozofia nie jest ani kontemplacją, ani komunikowaniem idei. Nie jest także refleksją nad myślącym podmiotem. Jest działalnością polegającą na nieograniczonym tworzeniu pojęć, wraz z nimi sposobów życia" (Bogusz-Bołtuć 2014, s. 51). Akcent położony jest tu na słowie „nieograniczone”, co zdaje się ma podkreślać podmiotowość, kreatywność i praktyczność tej działalności (sposobu życia?). Filozofia w tym kontekście ma się 
są filozoficznie (etycznie) ważne, o ile pretendują do bycia „opowieściami o rzeczywistości" i że należy je weryfikować (choćby ci, którzy je opowiadają protestowali, twierdząc, że nie ma tu prawdy obiektywnej, uniwersalnej, co najwyżej występują „prawdy lokalne"). Uczniowie powinni utwierdzać się w świadomości, że sądy i przekonania o rzeczywistości ostatecznie powinny być ich własnymi sądami i żaden autorytet nie możne znieść z nich samych odpowiedzialności za to, co uznają za prawdziwe i dobre. „W czasie przyswajania filozofii konieczne jest bycie świadomym tego, iż podmiotem jej dociekań jesteśmy my sami: zarówno nauczyciele, jak i uczniowie" - stwierdza Halina Romanowska-Łakomy (2014, s. 45-49), podkreślając wartość szeroko rozumianego doświadczenia jako koniecznego elementu „nauczania” filozoficznego ${ }^{17}$.

Procedura podwójnej weryfikacji, obiektywnej (we wspólnocie społecznej) oraz subiektywnej (odniesienie do własnego doświadczenia), ma także ważny walor dydaktyczny. Pozwala odnaleźć wspólne płaszczyzny dyskusji i sporu - nie stają się one bezprzedmiotowe ani nudne w swej ogólnikowości; nawet bowiem wtedy, kiedy ktoś zagubi się w argumentacji, a i słuchacze przestaną rozumieć, o co w dyskusji chodzi, zawsze można „zejść na ziemię" i spróbować na nowo sformułować problem, i można się spodziewać, że przyniesie to efekty, pod warunkiem że problem ten ma rzeczywiste, a nie wydumane źródła.

Także weryfikacja subiektywna pozwala utworzyć wspólną płaszczyznę, choć już na innej zasadzie, pomaga w „wymianie doświadczeń”, a więc we wskazywaniu i zachęcie, aby doświadczenia przeżywane przez kogoś na sposób subiektywny (inaczej nie mogą być przeżywane), ktoś inny mógł również przeprowadzić („na sobie”), odwołać się do nich i je zinterpretować. Wewnętrzne doświadczenia są silniejsze i trwalsze, filozofia daje szansę, aby to, co przeżywane subiektywnie, nie stało się powodem izolacji, lecz służyło komunikacji między ludźmi. Co ważne, ta „wspólnota komunikacji” może powstać między nauczycielem a uczniami, a także między uczniami a autorem tekstów - filozofem. Nie wydaje się to jednak możliwe bez podkreślenia, że i sfera subiektywna jest podporządkowana w aspekcie poznawczym - kryterium prawdy, a w aspekcie działania - dobru. Warto również pamiętać, że dobrze ukierunkowana wiedza o sobie jest również wiedzą o (każdym) człowieku; wiedza jednostkowa, niepoddająca się uniwersalizacji, może być również pożyteczna dla innych (jako rezultat dobrego rozpoznania siebie).

\section{Nauczyciel zaangażowany?}

Jedną z najważniejszych kwestii jest sprawa zaangażowania i bezstronności nauczyciela. Wielość stanowisk w filozofii i etyce, różnorodne próby stawiania

nijak do obiektywnej (czy subiektywnej) rzeczywistości. Jej stwierdzenia nie są ani prawdziwe, ani dyskusyjne, a co najwyżej „interesujące” czy „godne uwagi” (Bogusz-Bołtuć 2014, s. 63).

17 Warto przypomnieć, że ten postulat, zdaniem fenomenologów, dotyczy nie tylko „nauczania”, ale każdego dobrego przekazu filozoficznego. 
i rozwiązywania problemów dodatkowo komplikują problem i zdają się przemawiać na rzecz postawy neutralności, zwłaszcza wobec realnego niebezpieczeństwa ideologizacji przekazu. Teoretycznie kwestia nie wydaje się beznadziejna, znacznie trudniejsze jest znalezienie rozwiązań praktycznych. Ważne w tym przypadku jest precyzyjne określenie tego, co rozumiemy przez neutralność (bezstronność), a co przez zaangażowanie. Wydaje się, że nie może chodzić o neutralność samych poglądów nauczyciela, taki postulat byłby absurdalny, lecz o inne kwestie, takie jak: sposób prezentowania poglądów filozoficznych, kryteria oceny poglądów/ stanowisk/opinii wyrażanych przez uczniów, zakres swobody nauczyciela w prezentowaniu uczniom własnego stanowiska (występowanie z pozycji autorytetu/ uczestnika dyskusji).

Wypada zauważyć, że sytuacja, w której nauczyciel udaje, że nie ma własnego stanowiska lub je ukrywa, stwarza również wiele problemów: może podważać lub zrywać więź nauczyciela z uczniami, a samą dyskusję czynić sztuczną ${ }^{18}$. Natomiast dyskusja, w której nauczyciel jest równocześnie autorytetem/sędzią i uczestnikiem, jest możliwa, jeżeli nie będzie on narzucał uczniom własnej opinii, pozostawi im swobodę wypowiedzi oraz wyboru własnego stanowiska wobec przedstawionych argumentów (który przecież i tak mają i nikt im go nie może odebrać, choć nie zawsze są tego świadomi). Ujawnienie przez nauczyciela jego własnych poglądów (w jakiej formie, w jakim czasie - to sprawa osobna) rozjaśnia punkt wyjścia uczniowie wiedzą, kto do nich mówi, jakie ma przekonania. Zapewne nie musi (nie powinien) dokonywać tego wprost, zwłaszcza w trakcie dyskusji, aby „nie przytłoczyć" uczniów swoją argumentacją i autorytarną postawą.

Zaangażowanie teoretyczne nauczyciela i jasno wyrażone przez niego jego osobiste stanowisko $\mathrm{w}$ danej kwestii nie musi przeszkadzać zasadniczemu celowi, jakim jest ukształtowanie w młodym człowieku dojrzałej i odpowiedzialnej aktywności intelektu i woli, a więc umiejętności rozpoznawania prawdy i dobra. Można powiedzieć, że zaangażowanie nie przeciwstawia się bezinteresowności wtedy, kiedy rozumiemy je jako bezinteresowne zaangażowanie w prawdę i w realizację dobra. Warto przypomnieć, że taka postawa bywa dla nauczyciela trudna i wymaga stałej czujności dotyczącej wypowiadanych sądów, wartości własnego (prezentowanego/ głoszonego) stanowiska. Zwykle bezpieczniej i wygodniej jest zachować pozycję neutralną, a więc tylko przytaczać czyjeś poglądy, referować je. Jest to niewątpliwie pożyteczna umiejętność, wydaje się jednak, że lekcje filozofii/etyki mogą stać się wyjątkową okazją, aby uczniowie i nauczyciel starali się przedstawiać własne opinie, utwierdzać się we własnym widzeniu świata lub to widzenie podważać, dyskutować o tym, jak jest „naprawdę”. Takie otwarcie jest obarczone ryzykiem - kiedy bowiem rzetelnie przystępujemy do dyskusji, nie możemy być pewni, co

18 O kwestii zaangażowania ideologicznego nauczyciela filozofii piszą Marcin Dudek i Ignacy Szczeniowski, słusznie zwracając uwagę, że podkreśla ono wyjątkowość filozofii, ale również ma znaczenie dydaktyczne (Dudek, Szczeniowski 2014). 
z niej wyniknie. I nie chodzi o to, kto zwycięży w tej „grze” na słowa i argumenty, lecz o to, co uczestnicy w jej trakcie odkryją: może będą musieli zmodyfikowaćl zmienić swoje stanowisko. Dotyczy to również nauczyciela (zachowanie autorytetu w takiej sytuacji to osobna i bardzo delikatna kwestia). Nie ulega wątpliwości, że rozmowa, która choć w części zawierałaby po obydwu stronach nastawienie na wspólne poszukiwanie prawdy, stwarzałaby silną więź, a równocześnie, dzięki prawdzie, pozwalałaby utwierdzać się również w odpowiedziach, przekraczając zaklęte koło samych pytań i wątpliwości.

Przekonanie o potrzebie nauczania filozofii i etyki nie może zastąpić namysłu i ostrożności we wprowadzaniu tego projektu. Zadania nauczyciela są ambitne i obszerne: przekazywanie wiedzy wstępnej, inspirowanie, wskazywanie problematyczności wielu - wydawałoby się oczywistych - kwestii, nakłanianie do podejmowania samodzielnego rozpoznawania rzeczywistości i umiejętnego korzystania z własnego doświadczenia. I nie mogą być inne ze względu na charakter wiedzy, która jest wyjątkowa, sięga korzeni, granic ludzkiego poznania. Jest również wyjątkowa dlatego, że nie jest tylko wiedzą; postuluje postawę życiową (poszukiwanie mądrości), a nawet - realizowanie jej w życiu. Stawia to nauczyciela etyki w sytuacji odmiennej niż w przypadku większości innych przedmiotów; lekcje nie mogą być takie jak inne, a on sam powinien wyjść poza rolę rutynową, nie może ograniczyć się do roli „specjalisty”. Jest to dodatkowe obciążenie dla nauczyciela, który staje się nie tylko obserwatorem i autorytetem rozstrzygającym intelektualne spory, ale jest również współuczestnikiem i towarzyszem egzystencjalnych poszukiwań młodych ludzi. Powinien mieć również świadomość, że filozofia może być niebezpieczna dla kogoś, kto chciałby nieumiejętnie i nieostrożnie realizować w życiu poddawane pod dyskusję różnorodne propozycje filozoficzne, ulegając tylko ich atrakcyjności czy oryginalności. W pewnym więc stopniu nauczyciel odpowiada za to, jakie „mikstury" daje do ręki młodym adeptom i jak uczy ich używać. Wszystkie te względy sprawiają, że nauczaniu filozofii i etyki stale powinna towarzyszyć czujność, krytycyzm i ostrożność we wszelkim eksperymentowaniu.

\section{Bibliografia}

Bogusz-Bołtuć E. D. (2014). Czy można nauczyć filozofii. W: Kamińska W., Mroczkiewicz P. (red.). Jak uczyć, by nauczyć filozofii. Refleksje akademików i praktyków. Warszawa: Wydawnictwo UKSW, s. 51-65.

Dudek M., Szczeniowski I. (2014). W: Kamińska W., Mroczkiewicz P. (red.). Jak uczyć by nauczyć filozofii. Refleksje akademików i praktyków. Warszawa: Wydawnictwo UKSW, s. 121-137.

Filek J. (2001). Filozofia jako etyka. Kraków: Wydawnictwo Znak. 
Jan Paweł II (1985). List do młodych całego świata. Watykan.

Kamińska W. (2014). Metodologiczna konstrukcja dziedziny dydaktyki etyki. Warszawa: Wydawnictwo UKSW.

Kamińska W., Jasiński M. (2014). Filozofia a inne przedmioty. Próba ukazania możliwej korelacji na płaszczyźnie metod. W: Kamińska W., Mroczkiewicz P. (red.). Jak uczyć by nauczyć filozofii. Refleksje akademików i praktyków (2014). Warszawa: Wydawnictwo UKSW, s. 51-65.

Kołakowski L. (2009). Mini wykłady o maxi sprawach. Kraków: Wydawnictwo Znak.

Romanowska-Łakomy H. (2014). O istocie przekazu wiedzy filozoficznej. Pierwszy warunek dobrego „nauczania” filozofii. W: Kamińska W., Mroczkiewicz P. (red.). Jak uczyć by nauczyć filozofii. Refleksje akademików i praktyków. Warszawa: Wydawnictwo UKSW, s. 45-49.

Wasilewski M. (2015). Pomiędzy jasna a ciemna strona mocy. Ty wybierasz... Podrecznik do etyki dla gimnazjum. Konstancin-Jeziorna: Rea.

\title{
PRIMUM NON NOCERE... REMARKS ABOUT THE DETERMINANTS OF PHILOSOPHICAL/MORAL EDUCATION
}

\begin{abstract}
The main question of this article is the problem of the aims, content and ways of realisation in philosophical/moral education. The author begins with two points: firstly, the formation of philosophical and moral reflexion is one of the most important indicator of mature personality; secondly, school ought to undertake upbringing duties. Practical realisation of that kind of education can bring also some troubles and risks for the right development of a young man's personality. Those troubles can be noticed on the ideological (crisis of Western civilization: the "truth question", scepticism) or didactic (subjects which are too difficult and too abstract, terminology unsuitable for young people) level. Proposition of "school philosophy" (ethics) contain the following postulates: 1) philosophy (ethics) ought be presented as selfless cognition and activity directed to the truth and to goodness; 2) youth ought to be aware that the proposition is only an introduction to philosophy, but "real philosophy” is still ahead of them; 3) education ought to be based rather on experience than on abstract knowledge; 4) all knowledge has to be verifiable. The last considered point is the question of the teacher's engagement in teaching.
\end{abstract}

Keywords: philosophical education, moral education, experience, abstract knowledge, teacher's engagement.

Witold Starnawski - doktor habilitowany, zatrudniony na stanowisku prof. nadzw. na Wydziale Nauk Pedagogicznych Uniwersytetu Kardynała Stefana Wyszyńskiego w Warszawie. Zainteresowania naukowe: filozofia wychowania, pedagogia osoby, myśl Jana Pawła II, etyka. Publikacje książkowe: Prawda podstawa wspólnoty. Wychowawcza 
rola prawdy wedlug Karola Wojtyly (Warszawa 2005), Prawda jako zasada wychowania. Podstawy pedagogii personalistycznej w nawiazaniu do myśli Karola Wojtyły - Jana Pawła II (Warszawa 2008) i Bycie osobą. Podstawy moralności i wychowania (Warszawa 2011). Adres do korespondencji: Wydział Nauk Pedagogicznych UKSW, ul. Wóycickiego 1/3, budynek 15, 01-938 Warszawa. Adres e-mailowy: w.starnawski@uksw.edu.pl. 